\title{
Zelfstandige training in consultvoering: studenten leren van de simulatiepatiënt en van elkaar
}

\author{
L. Aper, J. Reniers, S. Koole, M. Valcke, A. Derese
}

\section{Samenvatting}

Inleiding: Een patiëntgericht consult vormt de basis voor goede medische zorgverlening. Studenten voorbereiden op deze complexe vaardigheid is een kerntaak van de medische opleiding. Aan de Universiteit Gent worden tijdens de masteropleiding trainingen consultvoering georganiseerd waarbij communicatieve en klinische redeneervaardigheden worden geïntegreerd. Studenten oefenen met een simulatiepatiënt onder supervisie van een docent. Deze studie onderzoekt een zelfstandige werkvorm zonder de aanwezigheid van een docent, waarbij simulatiepatiënten en studenten onderling feedback geven. De vraagstelling van dit onderzoek luidt: 1) Hoe percipiëren studenten de training? 2) Leidt de observatie van elkaar en de feedback van de simulatiepatiënt tot een leereffect? 3) Is de werkvorm efficiënter ten aanzien van docentbelasting?

Materiaal en methoden: In 2009/2010 werd in het tweede jaar van de masteropleiding in een pilotonderzoek de klassieke training met docent vergeleken met een zelfstandige werkvorm met afsluitende groepsbespreking. In deze werkvorm zonder docent geeft de simulatiepatiënt alleen feedback vanuit patiëntperspectief; de medestudent geeft feedback over de structuur en inhoud van het consult. De studenten kregen een schriftelijke vragenlijst ter evaluatie van de beide werkvormen. De observatielijst van de simulatiepatiënten werd gebruikt om het leereffect vast te stellen.

Resultaten: Analyse van de studentenpercepties toonde geen significante verschillen aan tussen de twee trainingsvormen. Wat betreft het leereffect binnen de zelfstandige werkvorm krijgt de student-arts een significant hogere score van de simulatiepatiënt. Ondanks de tijdwinst voor docenten is de training en follow-up van simulatiepatiënten wel een intensieve bezigheid.

Discussie en conclusie: Deze werkvorm wordt door studenten heel waardevol bevonden. Het stimuleert hun zelfvertrouwen en het leren feedback geven aan elkaar. Uit de afsluitende groepsbespreking met docent komt naar voren dat studenten zichzelf soms overschatten. Vervolgonderzoek naar het leereffect op lange termijn en de beste plaats in het curriculum wordt aanbevolen. (Aper L, Reniers J, Koole S, Valcke M, Derese A. Zelfstandige training in consultvoering: studenten leren van de simulatiepatiënt en van elkaar. Tijdschrift voor Medisch Onderwijs 2011;30(5):194-205.)

\section{Inleiding}

Medische consultvoering vormt een kerncompetentie van het arts zijn. ${ }^{1-3}$ Tegenwoordig omvat het arts-patiëntconsult meer dan het oplossen van een medisch probleem. Het gaat om het verbeteren van het patiëntenwelzijn in zijn/haar eigen context. Met andere woorden: een patiëntgericht consult. ${ }^{4}$ Dit begrip heeft in de literatuur al geruime tijd geleden zijn intrede gedaan en wordt nog steeds onder de loep genomen. ${ }^{5-7}$ De paternalistische rol van de arts binnen het traditioneel biomedisch model behoort tot het verleden. ${ }^{8}$ Een arts moet aandacht hebben voor de symptomen van de patiënt maar ook ruimte maken om de ideeën, bezorgdheden en verwachtingen te exploreren. ${ }^{9}$ Illingworth beschrijft patiënt- 
gerichtheid als een filosofie van de zorg die enerzijds focust op de patiënt als gehele persoon met zijn individuele voorkeuren binnen een welbepaalde context; anderzijds benadrukt hij het gezamenlijk nemen van beslissingen omtrent de therapie ('shared decision making'). Verschillende studies bevestigen het positieve effect van deze consultbenadering op zowel de patiënttevredenheid als de behandeling en therapietrouw. ${ }^{10-11}$ Silverman et al. geven aan dat patiëntgerichtheid en het communiceren met de patiënt net zo nauwkeurig onderwezen moeten worden als andere kerntaken, zoals het lichamelijk onderzoek.

Bij het aanleren van consultvaardigheden kan er sinds de jaren zestig een hele waaier van onderwijswerkvormen opgesomd worden: lezingen, observaties, papieren casussen, rollenspel met medestudenten, videobeelden van echte consulten, rollenspel met simulatiepatiënten, inzet van echte patiënten en acteurs, groepsdiscussies. ${ }^{12-18}$ In een review komen Lane en Rollnick tot de slotsom dat de interactieve methoden, waarbij rollenspellen en simulatiepatiënten wereldwijd gebruikt worden, het meeste aanslaan.

Aan de Universiteit Gent worden de consultvaardigheden in verschillende jaren onderricht. In de drie jaren van de bacheloropleiding krijgen studenten geneeskunde afzonderlijk onderwijs in communicatie en klinische vaardigheden. De trainingen in klinische consultvoering vinden plaats in het vierde, vijfde en zesde jaar. Deze omvatten een integratie van klinische redeneervaardigheden en communicatieve, technische onderzoeks- en behandelvaardigheden. Jaarlijks doorlopen de studenten per drie een carrousel van drie sessies waarbij steeds een simulatiepatiënt (SP) en docent/ arts aanwezig is. Binnen dit kleine groepsonderwijs wordt aan de hand van een theoretische leidraad de consultstructuur geoe- fend. Eén sessie duurt 40 minuten; hierbij wordt het consult in drie delen opgesplitst: opening/anamnese - klinisch onderzoek uitleg, advies en planning. Elke student neemt binnen de sessie de artsrol op zich voor één consultonderdeel en krijgt onmiddellijk persoonlijke feedback van de docent. Deze opsplitsing zorgt ervoor dat de drie studenten aangezet worden actief mee te werken tijdens de sessie. Carroll en Monroe benadrukken het belang van directe observatie en feedback bij het leren van consultvaardigheden. ${ }^{10}$

Door het arbeidsintensieve karakter van dit kleine groepsonderwijs, de toenemende studentenpopulatie en het beperkte aantal beschikbare docenten, kan deze training slechts éénmaal per jaar plaatsvinden $(2,15$ uur per student). Daarom werd er gezocht naar een alternatieve methode om de training in consultvoering te intensiveren. Ook studenten zijn vragende partij voor meer oefenkansen. Het streven naar een trainingsvorm die docenten ontlast én studenten interactief laat oefenen, resulteerde in een nieuwe werkvorm met SP'en en peers, zonder aanwezigheid van een docent.

De literatuurreview van Bokken et al. ${ }^{19}$ bespreekt verschillende werkvormen waarin SP'en feedback geven. Deze feedback gaat veelal over klinische vaardigheden waarbij de anamnese en het klinisch onderzoek worden gescoord. Maar ook de communicatieve vaardigheden behoren tot het domein van de SP'en. Bokken et al. stellen de suggestie voorop dat SP'en in de eerste plaats het beste vanuit hun patiëntperspectief feedback geven. Niettemin gebeurt dit echter bij een minderheid van de opgesomde studies (in tien van de 49 studies). Aan de Queen's University Medical School in Canada ${ }^{20}$ geven SP'en feedback aan de student en maken hierbij gebruik van een checklist. Deze bestaat uit 18 items, zoals: Stelde de student zichzelf voor? Waren de vragen begrijpelijk? Verklaarde de student 
de resultaten van het klinisch onderzoek in relatie met uw symptomen? Ook Kneebone et al. ${ }^{21}$ en McManus et al. ${ }^{22}$ beschrijven een onderwijsprogramma waarin studenten consultvaardigheden oefenen en feedback ontvangen van een SP. In beide settings start het feedbackmoment steeds met de impressies van de student zelf over het consult: Wat ging er goed? Wat kan er verbeterd worden? Nadien volgt er feedback van de SP, tutor en/of medestudent. Tot slot concluderen we op basis van de reviewgegevens dat bij het onderwijs met patiëntfeedback meestal een docent aanwezig is (in acht van de tien studies). De docent kan de sessie sturen en op medisch inhoudelijk vlak begeleiden.

Bij de uitwerking van onze alternatieve training in consultvoering werden bovenstaande bevindingen meegenomen. In het studiejaar 2009/2010 werd voor tweedejaars masterstudenten een trainingsvorm ontwikkeld zonder docent. De doelstellingen van de training mét docent werden hierbij als richtlijn vooropgesteld. We zochten een antwoord op de volgende vragen:

1) Hoe percipiëren studenten de nieuwe werkvorm zonder docent vergeleken met de training met docent?

2) Leidt de observatie van elkaar en feedback van de SP binnen de zelfstandige werkvorm tot een leereffect?

3) Is deze werkvorm efficiënter ten aanzien van docentbelasting?

\section{Materiaal en methoden}

\section{Inrichting van de nieuwe werkvorm}

De rechtstreekse feedback van de SP over zijn/haar gevoel met betrekking tot het consult vormt een heel sterk leermiddel dat noch een medestudent, noch een docent kan meegeven. De SP kan in deze rol echter geen feedback geven over de consultstructuur, over de correcte uitvoering van het klinisch onderzoek en over inhoudelijke ele- menten. Om dit toch aan bod te laten komen werd de volgende werkvorm opgezet.

Eén student voert een volledig consult uit met een SP vanuit een gestandaardiseerde rol, terwijl een tweede student het consult observeert en beoordeelt aan de hand van een checklist. Het hele consult is opgedeeld in drie delen: opening/anamnese - klinisch onderzoek - uitleg, advies en planning/afsluiting. Na elk onderdeel volgt een time-out volgens een vast verloop. Het feedbackmoment start steeds met een zelfreflectie van de student-arts over het consult: Wat vond je dat je goed deed? Wat ging er minder goed? Hierop haakt de SP in met feedback vanuit zijn/haar patiëntgevoel: heeft hij/zij dit ook zo ervaren tijdens het consult? Het gebruik van een observatielijst helpt de SP met het geven van concrete feedback. Vervolgens geeft de medestudent feedback op basis van zijn/haar checklist over de structuur van het consult en over de inhoudelijke elementen van de anamnese. Voor het klinisch onderzoek en voor uitleg, advies en planning overleggen beide studenten respectievelijk over de uit te voeren onderzoeken en over de juiste diagnose en het daaruit volgende beleid. De SP sluit dit overleg af door de juiste antwoorden op papier aan de studenten te geven. Op deze manier blijft de student-arts inhoudelijk op het correcte spoor en kan hij met het consult verder gaan. De totale sessie neemt 40 minuten in beslag.

Tijdens een tweede consult met een andere SP wordt de student-observator arts en vice versa. Tenslotte is er in een kleine groep (acht tot twaalf studenten) een nabespreking met een docent waarbij alle onderwerpen (inhoudelijk, klinisch onderzoek, consultstructuur, contact met de SP) worden besproken. Studenten krijgen de opdracht een leervraag te formuleren die tijdens deze groepsbespreking aan bod komt. Het onmiddellijk herbekijken van video-opnames is technisch nog niet mogelijk. Tabel 1 toont 
Tabel 1. Overzicht van de wijze waarop beide trainingen de onderwijsdoelstellingen bereiken.

\begin{tabular}{|c|c|c|}
\hline $\begin{array}{l}\text { Specifieke onderwijs- } \\
\text { doelstellingen }\end{array}$ & $\begin{array}{l}\text { Werkvorm met docent } \\
\text { Carrousel van drie sessies }\end{array}$ & $\begin{array}{l}\text { Zelfstandige werkvorm } \\
\text { Carrousel van twee sessies met } \\
\text { nabespreking in groep }\end{array}$ \\
\hline \multirow[t]{2}{*}{$\begin{array}{l}\text { Student oefent de } \\
\text { consultstructuur }\end{array}$} & $\begin{array}{l}\text { Student neemt in elke sessie de rol } \\
\text { van arts op zich voor één van de } \\
\text { drie consultonderdelen }\end{array}$ & $\begin{array}{l}\text { Student neemt in één sessie de rol van } \\
\text { arts op zich voor het hele consult }\end{array}$ \\
\hline & Feedback van docent & $\begin{array}{l}\text { Feedback medestudent aan de hand } \\
\text { van observatielijst structuur consult }\end{array}$ \\
\hline $\begin{array}{l}\text { Student oefent de klinische } \\
\text { vaardigheden }\end{array}$ & Feedback van docent & $\begin{array}{l}\text { Feedback van medestudent aan de } \\
\text { hand van observatielijst klinisch } \\
\text { onderzoek }\end{array}$ \\
\hline $\begin{array}{l}\text { Student oefent de } \\
\text { communicatieve } \\
\text { vaardigheden, het arts- } \\
\text { patiënt contact }\end{array}$ & Feedback van docent & Feedback van SP en van medestudent \\
\hline $\begin{array}{l}\text { Student leert door observatie } \\
\text { van medestudent }\end{array}$ & $\begin{array}{l}\text { In elk van de drie sessies observeert } \\
\text { de student twee medestudenten } \\
\text { als arts }\end{array}$ & $\begin{array}{l}\text { In één sessie observeert de student de } \\
\text { medestudent als arts }\end{array}$ \\
\hline $\begin{array}{l}\text { Student overlegt over } \\
\text { medisch inhoudelijke } \\
\text { elementen }\end{array}$ & $\begin{array}{l}\text { Met twee medestudenten en } \\
\text { een docent }\end{array}$ & Met één medestudent \\
\hline $\begin{array}{l}\text { Student leert de integratie } \\
\text { op medisch inhoudelijk vlak } \\
\text { (keuze van onderzoeken, } \\
\text { diagnosebepaling en therapie) }\end{array}$ & Begeleiding en feedback van docent & $\begin{array}{l}\text { Onderling overleg tussen studenten } \\
\text { Antwoorden op papier gegeven } \\
\text { Mogelijkheid tot vragen aan docent in } \\
\text { nabespreking }\end{array}$ \\
\hline $\begin{array}{l}\text { Student reflecteert over eigen } \\
\text { kunnen }\end{array}$ & Docent stimuleert reflectie & $\begin{array}{l}\text { De student-arts start met een reflectie } \\
\text { over wat goed/minder goed ging }\end{array}$ \\
\hline $\begin{array}{l}\text { Student leert het perspectief } \\
\text { van de patiënt kennen }\end{array}$ & Indirecte feedback van docent & Rechtstreekse feedback van de SP \\
\hline \multicolumn{3}{|l|}{ Praktische aspecten } \\
\hline \multirow[t]{2}{*}{ Tijdsindeling } & Drie sessies: elk 40 minuten & $\begin{array}{l}\text { Twee sessies: elk } 40 \text { minuten } \\
\text { Nabespreking in groep met arts: } \\
40 \text { minuten }\end{array}$ \\
\hline & 2,15 uur & 2,15 uur \\
\hline \multirow[t]{2}{*}{ Groepsindeling } & $\begin{array}{l}\text { Drie studenten, één docent, } \\
\text { één SP }\end{array}$ & Twee studenten, één SP \\
\hline & & Eén docent voor nabespreking \\
\hline Sturing van de sessie door & Docent & SP \\
\hline
\end{tabular}


aan waar de training met docent en de zelfstandige training elkaar overlappen en tegemoet komen. De training met docent vraagt per student 2,15 uur onderwijstijd. Vanuit organisatorisch oogpunt werd de nieuwe werkvorm binnen dit zelfde tijdpad uitgewerkt. Vandaar de keuze voor twee casussen en één nabespreking in de groep.

\section{Selectie en trainingen van de simulatiepatiënt}

In deze proeffase werden SP'en geselecteerd op basis van twee criteria: een ruime ervaring met het spelen van gestandaardiseerde rollen in de training met docent en hun capaciteit om het functioneren van de student correct te observeren.

Binnen de zelfstandige werkvorm krijgen de SP'en een viervoudige opdracht toebedeeld. De SP'en spelen allereerst op een spontane manier hun rol volgens een gestandaardiseerd script. Ten tweede observeren ze tegelijkertijd de handelwijze van de student en geven ze hun bevindingen na elk consultonderdeel weer op een observatielijst. Ten derde geven ze feedback vanuit hun patiëntgevoel aan de student-arts op basis van hun observaties. Tot slot modereren de SP'en het verloop van de sessie.

Om aan deze viervoudige opdracht te kunnen voldoen werd een intensief trainingsprogramma opgezet. Concreet werden er acht SP'en getraind in twee groepen. Het programma bestond uit vijf sessies van steeds een halve dag: een inleiding, tweemaal rollenspel met skillslabdocent, een observatie bij reeds getrainde SP'en en een rollenspel met student-vrijwilligers. Vanaf de eerste sessie krijgen de SP'en via een observatielijst een aantal concrete handvatten mee om feedback te geven: Stelt de arts zich voor en vraagt hij mijn naam? Kan ik mijn verhaal vertellen? Gebruikt de arts voor mij begrijpelijke taal?

\section{Evaluatie}

Tijdens het studiejaar 2009/2010 werd een pilotonderzoek opgezet waarbij 60 studenten deelnamen aan de zelfstandige werkvorm met een nabespreking in groepsverband. 72 studenten volgden de training met docent. De onderwijstijd (2,15 uur) en de casussen (radiculopathie, spanningshoofdpijn, voorbijgaande ischemische aanval, meniscusletsel) waren in beide groepen dezelfde. Onmiddellijk na de werkvorm gaf een onafhankelijke projectmedewerker van het Centrum voor Onderwijsontwikkeling aan de studenten een schriftelijke vragenlijst (tien stellingen met een vijfpunts Likertschaal) en twee open vragen:

1) Hebt u nog andere inhoudelijke opmerkingen over de training? (Gelieve deze hier neer te schrijven).

2) Hebt u praktische opmerkingen over de training? (Gelieve deze hier neer te schrijven).

De werkvorm met docent werd voorgaande jaren reeds mondeling geëvalueerd. De zelfstandige werkvorm was volledig nieuw waardoor het onmiddellijk ontvangen van rechtstreekse feedback belangrijk was: in de nabespreking werd gepeild naar de ervaring van de studenten. De training met docent hadden de studenten het voorgaande jaar al doorlopen waardoor zij beide werkvormen konden vergelijken.

Binnen de zelfstandige werkvorm gaven de SP'en op basis van hun observatielijsten per consultitem een kwalitatieve beoordeling van de studenten (goed, matig, slecht). Om het leereffect van sessie 1 naar sessie 2 vast te stellen, werden deze woordscores omgezet in een cijfer (goed $3 / 3$, matig $2 / 3$, slecht $1 / 3$ ). In de training met docent was het praktisch niet mogelijk dat de SP'en een beoordeling gaven. Deze SP'en waren niet getraind in het correct observeren en beoordelen. Daarnaast zou de feedback van de docent de 
mening van de SP eventueel kunnen beinvloeden.

\section{Statistische analyse}

De uitkomst van de schriftelijke bevraging en de studentenobservaties van de SP'en worden weergegeven met het gemiddelde \pm de standaarddeviatie. De statistische verwerking gebeurde via de Independent Sample T-test in SPSS 17.0.

\section{Resultaten}

\section{Studentenpercepties omtrent de training}

Uit de schriftelijke bevraging van de studenten blijkt dat er geen significante verschillen zijn tussen de training met docent en de zelfstandige werkvorm zonder docent. Tabel 2 laat de gemiddelde scores zien per stelling. Studenten bevestigen de zinvolheid van de oefening. Concreet helpt het hen de communicatieve vaardigheden, de structuur van het consult, de uitvoering van een gestructureerde anamnese en een systematisch klinisch onderzoek te oefenen. Zowel de feedback van de simulatiepatiënt als van de docent worden als zeer waardevol ervaren. De meerwaarde van de docent kan opgemerkt worden bij vrijwel alle stellingen die in lichte mate hoger scoren op een schaal van 1-5: "Mijn kennis van de structuur van het consult is toegenomen: (werkvorm met docent: 4.18 tegenover zelfstandige werkvorm: 3.96)" "De casussen verduidelijken de relatie tussen de praktijk en de structuur van het consult (werkvorm met docent: 4.31 tegenover zelfstandige werkvorm: 4.09)". In contrast

Tabel 2. Studentenpercepties met betrekking tot de twee onderwijswerkvormen.

\begin{tabular}{lcc}
\hline $\begin{array}{l}\text { Maart 2010 } \\
\text { Stellingen met betrekking tot de werkvorm } \\
\text { (met vijfpunts Likertschaal) }\end{array}$ & $\begin{array}{c}\text { Werkvorm } \\
\text { met docent } \\
\text { (72 studenten) } \\
\text { Gem. } \pm \text { SD }\end{array}$ & $\begin{array}{c}\text { Zelfstandige } \\
\text { werkvorm } \\
\text { (60 studenten) } \\
\text { Gem. } \pm \text { SD }\end{array}$ \\
\hline $\begin{array}{l}\text { Het doorlopen van deze consultaties helpt me de structuur van het } \\
\text { consult te oefenen }\end{array}$ & $4.69 \pm 0.47$ & $4.58 \pm 0.50$ \\
$\begin{array}{l}\text { Het zien van de interactie arts-patiënt doet me stil staan bij het } \\
\text { waarom van de consultstructuur }\end{array}$ & $4.23 \pm 0.60$ & $4.11 \pm 0.79$ \\
$\begin{array}{l}\text { Naast de structuur van het consult oefende ik ook het } \\
\text { communicatieve aspect van de consultatie }\end{array}$ & $4.50 \pm 0.53$ & $4.44 \pm 0.57$ \\
$\begin{array}{l}\text { De casussen verduidelijken de relatie tussen de praktijk en de } \\
\text { structuur van het consult }\end{array}$ & $4.31 \pm 0.63$ & $4.09 \pm 0.70$ \\
$\begin{array}{l}\text { Kijken naar de wijze waarop de arts de anamnese doorloopt, helpt } \\
\text { me bij het ontwikkelen van mijn eigen systematiek }\end{array}$ & $4.29 \pm 0.65$ & $4.13 \pm 0.70$ \\
$\begin{array}{l}\text { Het zoeken naar fouten bij het klinisch onderzoek helpt me de } \\
\text { specifieke testen weer op te frissen }\end{array}$ & $4.38 \pm 0.65$ & $4.11 \pm 0.83$ \\
$\begin{array}{l}\text { De feedback vond ik waardevol } \\
\text { (gedifferentieerd: docent/SP) }\end{array}$ & $4.62 \pm 0.55$ & $4.49 \pm 0.57$ \\
$\begin{array}{l}\text { Globaal ben ik tevreden over mijn prestatie } \\
\text { Ik vind het zinvol om deze oefening te doorlopen }\end{array}$ & $3.57 \pm 0.94$ & $3.64 \pm 0.68$ \\
\begin{tabular}{l} 
Mijn kennis van de structuur van het consult is toegenomen \\
\hline
\end{tabular} & $4.51 \pm 0.56$ & $4.71 \pm 0.50$ \\
\hline
\end{tabular}


daarmee scoren de tevredenheid over de eigen prestatie en de beoordeling van de zinvolheid bij de zelfstandige werkvorm iets hoger.

De kwalitatieve data van de vragenlijst en mondelinge nabespreking worden in drie clusters samengebracht: 1) Leerzaamheid, 2) Vraag naar meer en 3) Zelfstandig aspect. In Box 1 wordt een aantal studentenreacties opgesomd. Globaal zijn alle studenten lovend over de zinvolheid van de werkvorm. Een heel consult uitvoeren in de rol van arts geeft hen een duidelijker beeld over hun eigen kunnen. Studenten geven wel aan dat één training per jaar beperkt is. Het meerdere malen organiseren van deze training zou hen de kans geven te leren uit hun fouten en het beter te doen. Tot slot leidt het zelfstandig werken bij een groot aantal studenten tot meer zelfvertrouwen. Studenten voelen zich vrijer in het geven van eerlijke feedback aan elkaar.

\section{Leereffect door observeren en feedback geven aan een medestudent}

Uit de observatielijst van de SP'en blijkt concreet dat de arts in sessie 2 significant hoger scoort op een aantal consultitems, bijvoorbeeld: in sessie 1 stelt de arts zichzelf minder vaak voor waarop de patiënt in de feedback nadien aangeeft:

"Ik had het toch wel aangenaam gevonden mocht ik uw naam weten, nu ga ik buiten en kan ik thuis niet vertellen wie ik voor had."

In de eerste sessie geeft de arts minder vaak ruimte voor het idee of de bezorgdheid van de patiënt:

"Ik vind het jammer dat ik niet heb kunnen vertellen wat ik zelf over mijn hoofdpijn denk. Ik kreeg er de ruimte niet voor, $u$ vroeg mij onmiddellijk waar die pijn precies zit. Als ik nu naar huis ga blijf ik
Box 1. Inhoudelijke en praktische opmerkingen van de studenten in de drie clusters.

\section{Cluster 1: Leerzaamheid}

“De onmiddellijke feedback zowel van de medestudent als van de SP is zeer nuttig. Het is zowel voor de klinische als de communicatieve vaardigheden zeer leerrijk."

"Zeer goede manier om communicatie/ 'artsenskills' te oefenen!! Beter dan theorieles en oefeningensessies in grote groepen."

"Dit is de beste manier van trainen."

"Zeer aangename en bruikbare vorm van onderwijs."

"Zeer goede training."

"Zeer goede manier om consult en communicatie in te oefenen, goed om feedback te krijgen."

\section{Cluster 2: Vraag naar meer}

"Ik vind het een bijzonder leerzame ervaring, men zou deze training meer op regelmatige basis moeten kunnen organiseren $(3 \mathrm{x}$ per jaar; dit is zo'n cruciale vaardigheid dat deze doelstelling de organisatorische moeite loont."

"We zouden dit soort oefeningen frequenter moeten kunnen doen om zelfverzekerder op stage te staan."

“Meer met SP'en."

"Graag meer oefening."

\section{Cluster 3: Zelfstandig aspect}

"Afwezigheid docent stimuleert het spontane verloop, medestudent durft kritiek te geven zonder docent erbij."

"Vorig jaar zat er een arts bij, arts is niet nodig."

"Een aanrader!! SP'en waren zeer hulpvol en goed getraind!"

"Zeer goed met SP in plaats van dokter, vorig jaar zat er een dokter bij. 
met de twijfel zitten of het dan toch geen tumor zou kunnen zijn."

In de tweede sessie neemt de observator uit het vorige consult de rol van arts op zich en worden bovenstaande twee items significant hoger gescoord. Tabel 3 toont de andere items van het consult die significant beter verlopen in sessie 2 : er wordt een meer verstaanbare uitleg gegeven over de diagnose en er wordt beter teruggekoppeld naar de specifieke verwachting van de patiënt.

\section{Efficientie op het vlak van de docentbelasting}

De training met docent vraagt voor vierentwintig studenten per halve dag zestien docenturen en vijf SP'en (vier SP'en voor vier sessies en één reserve). Voor hetzelfde aantal studenten vraagt de zelfstandige trai- ning met nabespreking in groepsverband twee docenturen en zeven SP'en (zes SP'en voor zes sessies en één reserve). Het trainen van SP'en bij de zelfstandige werkvorm eist verhoudingsgewijs meer begeleiding. Naast de oefening van een nieuw script (vier docenturen / twee sessies) neemt het trainen van SP'en in het feedback geven éénmalig vijf sessies van vier uren in beslag (Tabel 4). De follow-up van de SP'en nadien is naar docentbelasting ook intensiever: video-opnames worden in kleine groep herbekeken en besproken.

\section{Discussie}

In dit onderzoek wordt een zelfstandige onderwijswerkvorm, waarbij studenten met een SP en medestudent de consultstructuur oefenen, opgestart en geëvalueerd. Binnen deze werkvorm leert de student het perspec-

Tabel 3. Overzicht van de gemiddelde scores van de acht simulatiepatiënten.

\begin{tabular}{lcc}
\hline Items uit de observatielijst & $\begin{array}{c}\text { Sessie } 1 \\
\text { Gem. } \pm \text { SD }\end{array}$ & $\begin{array}{c}\text { Sessie } 2 \\
\text { Gem. } \pm \text { SD }\end{array}$ \\
\hline De arts stelt zichzelf voor en vraagt mijn naam & $2,28 \pm 0.84$ & $2,71 \pm 0.58^{*}$ \\
Ik kan mijn volledige verhaal vertellen & $1,83 \pm 0.84$ & $2,10 \pm 0.86$ \\
Ik krijg de ruimte om mijn eigen ideeën te vertellen / bezorgdheid te uiten & $1,43 \pm 0.68$ & $1,86 \pm 0.90^{*}$ \\
Ik kan mijn verwachting vertellen & $1,88 \pm 0.86$ & $1,82 \pm 0.84$ \\
De arts stelt duidelijke vragen & $2,68 \pm 0.48$ & $2,66 \pm 0.57$ \\
De arts vraagt mijn instemming met het klinisch onderzoek & $2,58 \pm 0.65$ & $2,71 \pm 0.66$ \\
Ik heb het gevoel dat de arts aandachtig naar mij luistert, mij begrijpt & $1,62 \pm 0.64$ & $1,95 \pm 0.75$ \\
De arts geeft duidelijke en correcte richtlijnen wat ik moet uitdoen & $2,52 \pm 0.69$ & $2,59 \pm 0.66$ \\
De arts geeft uitleg voor en tijdens het onderzoek & $1,94 \pm 0.74$ & $2,17 \pm 0.64$ \\
Ik voelde me veilig tijdens het onderzoek & $2,80 \pm 0.48$ & $2,82 \pm 0.38$ \\
Ik kreeg een duidelijke, verstaanbare uitleg over de diagnose & $2,19 \pm 0.83$ & $2,63 \pm 0.71^{*}$ \\
De arts kwam terug op mijn ongerustheid & $1,92 \pm 0.87$ & $1,97 \pm 0.93$ \\
De arts kwam terug op mijn verwachting & $2,17 \pm 0.82$ & $2,79 \pm 0.51^{*}$ \\
Ik kreeg de gelegenheid voor vragen & $1,88 \pm 0.77$ & $2,16 \pm 0.80$ \\
De arts gebruikt voor mij begrijpelijke taal & $2,73 \pm 0.53$ & $2,79 \pm 0.53$ \\
\hline
\end{tabular}

* significant bij $p<0.05$ 
Tabel 4. Overzicht docenturen.

\begin{tabular}{|c|c|c|}
\hline Docenturen & Werkvorm met docent & Zelfstandige werkvorm \\
\hline SP tijd & 4 uur (scripttraining) & 4 uur (scripttraining) \\
\hline Basistraining & & 20 uur (feedbacktraining $5 \times$ halve dag) \\
\hline $\begin{array}{l}\text { Lestijd voor halve dag } \\
\text { (voor } 24 \text { studenten) }\end{array}$ & 16 uur ( 4 docenten voor 4 sessies) & 2 uur (nabespreking in groep) \\
\hline (voor 216 studenten) & 144 uur (16 uur x 9 halve dagen) & 18 uur ( 2 uur $\times 9$ halve dagen) \\
\hline SP tijd & 2 uur (heropfrissing script) & 2 uur (herbekijken video-opname*) \\
\hline $\begin{array}{l}\text { Verdere follow-up per SP } \\
\text { (voor } 216 \text { studenten) }\end{array}$ & 14 uur (voor 7 SP'en**) & 20 uur (voor 10 SP'en $^{* *}$ ) \\
\hline $\begin{array}{l}\text { Totale docenttijd } \\
\text { (voor } 216 \text { studenten) }\end{array}$ & $\begin{array}{l}162 \text { uur (met } 7 \text { SP'en en } 9 \text { halve } \\
\text { dagen) }\end{array}$ & $\begin{array}{l}62 \text { uur (met } 10 \text { SP'en en } 9 \text { halve } \\
\text { dagen) }\end{array}$ \\
\hline
\end{tabular}

* herbekijken video-opname omvat een feedbackmoment voor de SP: zowel een opfrissing van het script als bijsturing in het observatievermogen van de SP en het verwoorden van patiëntgevoelens komen aan bod.

** in theorie zijn er respectievelijk 5 en 7 SP'en nodig; opdat aflossing mogelijk is wordt er steeds met een iets grotere groep gewerkt.

tief van de SP kennen en oefent de structuur van het consult zonder docent.

\section{Feedback door de simulatiepatiënt}

Bij de uitwerking van de zelfstandige werkvorm werden ideeën uit de literatuur meegenomen. Alvorens patiëntfeedback te ontvangen worden studenten verplicht schriftelijk te reflecteren over het zelf uitgevoerde consult als arts. Deze reflectie vormt het vertrekpunt van het time-outmoment. Daarnaast werd er voor gekozen SP'en te laten werken met een observatielijst. Dit document biedt concrete handvatten waardoor oppervlakkige feedback vermeden wordt.

Uit de resultaten van de bevraging omtrent het proefproject blijkt dat studenten de zelfstandige werkvorm als zeer zinvol ervaren. Het rollenspel met SP'en helpt bij het oefenen van de consultstructuur en de communicatieve vaardigheden. Luisteren naar de visie van de SP vinden de studenten heel leerzaam: er is aandacht voor wat goed liep en studenten ontvangen concrete werkpunten.

\section{In duo oefenen zonder docent}

Consultvoering leer je het beste door zelf te doen. Bij de twee beschreven werkvormen gaan studenten actief aan de slag. Daarnaast neemt de medestudent bij de zelfstandige werkvorm ook een heel belangrijke taak op zich: gericht observeren met een checklist en feedback geven. Uit dit onderzoek blijkt dat de student die de eerste sessie observeert, in een bevoorrechte positie zit: hij/zij kijkt hoe de medestudent het consult als arts uitvoert, hoort de feedback van de SP en geeft daarenboven zelf feedback aan de hand van een checklist. Uit de observaties van de SP'en blijkt dat de arts in de tweede sessie significant hoger scoort op een aantal consultitems. Het observeren van een consult tussen arts en patiënt, waarbij de patiënt aangeeft welke zaken voor hem/haar aangenaam en minder aangenaam waren, 
zorgt voor een positief leereffect naar de volgende sessie toe. Deze resultaten moeten wel gekaderd worden: de SP'en worden getraind in het observeren en feedback geven binnen een leersituatie, niet specifiek in het scoren van de student. Dat de student beter presteert in de tweede sessie ligt in lijn van de verwachtingen. In vervolgonderzoek moet het langetermijneffect van dit leren verder onderzocht worden.

Uit de kwalitatieve data leiden we af dat de afwezigheid van een docent tot een hogere zelfverzekerdheid leidt. Studenten geven aan zich vrijer te voelen in het geven van onderlinge feedback. Verder onderzoek is nodig om dit systematisch te testen. Een vergelijking tussen de zelfstandige werkvorm en de training met begeleider levert geen significante verschillen op, maar de training met docent scoort wel op vrijwel alle stellingen hoger. Het verschil is het grootste bij het bijbrengen van theoretische kennis, de consultstructuur en het beter verduidelijken van de relatie met de praktijk. Hieruit kunnen we - met de nodige reserve - afleiden dat de meerwaarde van een docent toch ligt in het leggen van nuances en in het verduidelijken van knelpunten naar een breder kader, toegepast op de praktijk.

\section{Inschatting van studenten}

Een laatste aandachtspunt omtrent de nieuwe werkvorm komt uit de nabespreking met docent waarbij vragen van studenten aan bod komen. De docent heeft inzage in de observatielijsten van de SP'en. Daaruit blijkt dat sommige studenten hun eigen prestatie na het zelfstandig doorlopen van de twee sessies overschatten. Een mogelijke verklaring hiervoor is het feit dat SP'en enkel vanuit hun patiëntperspectief feedback geven en de observerende student door gebrek aan kennis en inzicht minder kritisch is. Een docent streeft naar perfectie en nuancering zowel op het vlak van consultstructuur als binnen het medisch inhoudelijke en communicatieve domein. Zoeken naar de juiste plaats in het curriculum voor deze zelfstandige werkvorm kan dit probleem deels ondervangen.

\section{Docentbelasting}

Wat betreft docentbelasting kunnen we constateren dat de nieuwe werkvorm een verbetering is. Het efficiënt trainen en bijsturen van SP'en in het feedback geven is echter wel een intensieve bezigheid en vraagt voldoende financiële middelen. Vervolgonderzoek op dit terrein wordt aanbevolen.

\section{Conclusie}

We concluderen dat de zelfstandige werkvorm met nabespreking in groepsverband een waardevolle aanvulling vormt binnen het onderwijs in consultvoering. De sessies met docent vormen de basis, maar rekening houdend met het groeiproces van de student is deze nieuwe werkvorm een logische vervolgstap. De studenten zelf zijn lovend over de zinvolheid van de zelfstandige training. Het stimuleert hun zelfvertrouwen en ze voelen zich vrijer in het geven van eerlijke feedback aan elkaar. Binnen het concept van een 'patiëntgericht consult' biedt de feedback vanuit patiëntperspectief een toegevoegde waarde.

\section{Literatuur}

1. Novack D, Dubé C, Goldstein M. Teaching medical interview: a basic course on interviewing and the physician patient relationship. Arch Intern Med 1992;152(9):1814-20.

2. Van Thiel J, Kraan HF, Van Der Vleuten CP. Reliability and feasibility of measuring medical interviewing skills: the revised Maastricht history and advice checklist. Med Educ 1991;25(3):224-9.

3. Froelich RE. Programmed medical interviewing: a teaching technic. South Med J 1966; 59(3):281-3.

4. Marvel K, Major G, Jones K, Pfaffly C. Dialogues in the exam room: medical interviewing by resident family physicians. Fam Med 2000;32(9):628-32.

5. Stewart M, Brown JB, Weston WW, McWhinney IR, McWilliam CL, Freeman TR. Patient-centred medicine: transforming the clinical method. London: Thousand Oaks, Sage Publications; 1995. 
6. Illingworth R. What does 'patient-centred' mean in relation to the consultation? Clin Teach 2010;7:116120.

7. Bombeke K, Symons L, Debaene L, De Winter B, Schol S, Van Royen P. Help, I'm losing my patientcentredness! Experiences of medical students and their teachers. Med Educ 2010;44:662-673.

8. Jung HP. A systematic review of the literature on patient preferences regarding general practice care. Social Science and Medicine 1998;47(10):1573-1588.

9. Kinnersley P, Stott N, Peters TJ, Harvey I. The patient-centredness of consultations and outcome in primary care. Br J Gen Pract 1999 Sep;49(446):711-6.

10. Carroll JG, Monroe J. Teaching medical interviewing: a critique of educational research and practice. J Med Educ 1979;54(6):498-500.

11. Silverman J, Kurtz S, Draper J. Vaardig communiceren in de gezondheidszorg: een evidence-based benadering. Boom: Lemma tweede druk; 2006. [Skills for communicating with patients: an evidence-based approach].

12. Gillard S, Benson J, Silverman J. Teaching and assessment of explanation and planning in medical schools in the United Kingdom: cross sectional questionnaire survey. Med Teach 2009;31(4):328-31.

13. Deveugele M, Derese A, De Maesschalck S, Willems S, Van Driel M, De Maeseneer J. Teaching communication skills to medical students, a challenge in the curriculum? Patient Educ Couns 2005;53(3):265-270.

14. Lane C, Rollnick S. The use of simulated patients and role-play in communication skills training: a review of the literature to August 2005. Patient Educ Couns 2007; 67(1-2):13-20.

15. Kaplan CB, Siegel B, Madill JM, Epstein. Communication and the medical interview - Strategies for learning and teaching. J Gen Intern Med 1997; 12:S49-S55.

16. Froelich RE. A course in medical interviewing. J Med Educ 1969; 44(12):1165-9.

17. Rees C, Sheard C, McPherson A. Medical students' views and experiences of methods of teaching and learning communication skills. Patient Educ Couns 2004; 54(1):119-21.
18. Barrows HS. An overview of the uses of standardized patients for teaching and evaluating clinical skills. Acad Med 1993; 68(6):443-451.

19. Bokken L, Linssen T, Scherpbier A, van der Vleuten C, Rethans JJ. Feedback by simulated patients in undergraduate medical education: a systematic review of the literature. Med Educ 2009;43(3):202-10.

20. McGraw RC, O'Conner HM. Standardised patients in the early acquisition of clinical skills. Med Educ 1999;33(8):572-8.

21. Kneebone R, Kidd J, Nestel D, Asvall S, Paraskeva P, Darzi A. An innovative model for teaching and learning clinical procedures. Med Educ 2002;36 (7): 628-34.

22. McManus IC, Vincent CA, Thom S, Kidd J. Teaching communication skills to clinical students. BMJ 1993;306 (6888):1322-7.

De auteurs:

Drs. L. Aper is onderwijspedagoog/projectmedewerker aan het Centrum voor Onderwijsontwikkeling. *

Dr. J. Reniers is universitair docent en coördinator van het skillslab en huisarts. *

Drs. S. Koole is onderwijskundige/projectmedewerker aan het Centrum voor Onderwijsontwikkeling. *

Prof. dr. M Valcke is hoogleraar aan de Faculteit Psychologie en Pedagogische wetenschappen, Universiteit Gent en voorzitter van de vakgroep Onderwijskunde.

Prof. dr. A. Derese is hoofddocent, directeur skillslab, voorzitter Centrum voor Onderwijsontwikkeling en coördinator van de Specifieke Lerarenopleiding Gezondheidswetenschappen. *

* Allen zijn verbonden aan de Faculteit Geneeskunde en Gezondheidswetenschappen, Universiteit Gent.

Correspondentieadres:

L. Aper, Faculteit Geneeskunde en Gezondheidswetenschappen Universiteit Gent, Centrum voor Onderwijsontwikkeling, UZ 3K3, De Pintelaan 185, 9000 Gent. E-mail:leen.aper@ugent.be

Belangenconflict: geen gemeld

Financiële ondersteuning: geen gemeld 


\section{Summary}

Introduction: Patient-centred consultations are key to good medical care. Preparing students for this complex skill is a core task of medical education. At Ghent University, consultation skills training runs throughout the master phase (years 4-6) in sessions with a simulated patient and a supervising physician, aimed at integrating communication and clinical reasoning skills. We examined effects of a new training format with unsupervised sessions, and feedback from simulated patients and students by addressing the following research questions: 1) How do students perceive this training format? 2) Do patient feedback and mutual observation result in a learning effect? 3) Does the format reduce supervisor workload? Method: In 2009-2010, a pilot study among fifth year students compared the traditional format and the new format, in which simulated patients give feedback from the patient perspective and students give peer feedback on structure and content of the consultation. Students evaluated both formats by completing a questionnaire. Observation lists completed by simulated patients were used to determine any learning effects.

Results: The evaluation yielded no significant differences between the two formats. Simulated patient ratings of studentdoctor performance were significantly higher in the second session. Supervisor workload was reduced but training and follow-up of simulated patients remained time and labour intensive.

Discussion and conclusion: Students thought the new format was quite valuable. It improved their confidence and peer feedback skills. The closing group session with a supervisor showed that students overestimated their performance. Further studies should investigate long term learning effects and optimal placement in the curriculum of the new format. (Aper L, Reniers J, Koole S, Valcke M, Derese A. Consultation skills training without a supervisor: learning through feedback from simulated patients and peers. Netherlands Journal of Medical Education 2011;30(5):194-205.) 